\title{
Batik Guide Mobile Application Based Software with Java 2 Micro Edition (J2ME)
}

\author{
Tika Novita Sari, Amalia Ima Nur Jayanti, Rohmatus Naini, and Ratna Wardani
}

\begin{abstract}
The "Batik Guide" is an application that will make every user feel easier in learning the Batik of Indonesia. The aim of this research is to make the "Batik Guide" application and knowing the eligibility of this application. The research method is Research and Development ( $R \& D)$ method. Then, the authors simplified this method into 4 steps, those are: (1) Need Assessment, (2) Model design, (3) Implementation, and (4) Validation. This application is made by using Java Micro Edition programming language and MySQL database. The data sampling was taken in Museum Batik Yogyakarta and Batik Tjokrodiningrat. Some features in this application are batik description, batik trader addresses, batik course addresses, the history of batik, and some technique of making batik. The applications were made in 2 languages, Indonesian and English. There are 2 techniques in testing. They are Alfa Testing and Beta Testing. The Alfa Testing were tested to 2 professional multimedia lecturers and the result is $84,72 \%$ and it means this software is very appropriate to be used. The Beta Testing was given to domestic and foreign tourist. From 30 domestic tourists, the eligibility percentage is $92 \%$ and it means this software is very appropriate to be used. Then, 3 foreign tourists, said that this application is very helpful in learning Indonesian Batiks and the map is also make them easier to be used as a guidance to buy batik.
\end{abstract}

Index Terms-Batik, java, mobile application, tourists.

\section{INTRODUCTION}

Indonesia is a nation that has a wide range of wealth. Whether it's natural wealth, the wealth of art, or crafts wealth and many others. One manifestation of such national wealth is batik. Everyone in Indonesia knows about batik. Batik is a fabric craft that have many variant in motifs, colors, and ornaments original from Indonesia. It's made by hand (handicraft) or cap painting. Batik is the most popular crafts because of the unique beauty in batik cloth that gave deep meanings of pleasure for the lover of it.

Batik industry spread entire the country of Indonesia. The batik patterns have self-meanings of certain symbols that appropriate each region or province. Phenomenal existence of it makes other countries want to recognize batik as one of their inheritance culture. Therefore, Batik is patented as a cultural heritage in Indonesia. Nowadays, our duty is to maintain and preserve batik in order not to fall into the other countries. The ways is not only wearing it often, but also get to know the meanings of each batik patterns scratches. The

Manuscript received December 20, 2013; revised April 25, 2014

Tika Novita Sari, Amalia Ima Nurjayanti, and Ratna Wardani are with Engineering Faculty, Yogyakarta State University, Yogyakarta, Indonesia (e-mail: tikansari@gmail.com).

Rohmatus Naini is with Faculty of Education, Yogyakarta State University, Indonesia (e-mail: rohmatusnaini@ymail.com). unique characteristic of batik attracts a lot of foreign tourists. The tourists hunted many variant of batik from the regions. Based on the president's speech on 28 September 2011, total batik sales in 2006 is $\mathrm{Rp} 2.9$ trillion rupiahs and has increased to Rp 3.9 trillion in 2010 [1].

Based on the reason above, the author thinks how to make local and foreign tourists to know more about the original batik of Indonesia at anytime and anywhere easily. Thus the author making the work of Batik Guide based mobile application. This software will contain a wide variant of batik in Indonesia plus motif of batik's names and the production location (of that batik)-based on GPS (Global Positioning System) in each region batik. Since most tourists do not know the meaning of a batik.

This software will be packaging in the mobile applications that can run on any phone supports Java and GPS. Applications in mobile make this software can be used anywhere and anytime. This would provide high convenience and flexibility for tourists. An attractive interface design will attract more the tourist and enjoy to know (learn) all about batik in Indonesia. The latest data reported from the Association of Indonesian Cellular Telecommunications (ATSI), collected from 10 mobile telecommunications companies in the country, mobile penetration in Indonesia continues to rise and has now reached 110 percent of the total population [2].

Therefore, the authors propose a paper entitled: "Batik Software Guide-Based Mobile Application Using Language Programming Java 2 Micro Edition (J2ME)" to facilitate the tourists looking for batik distribution place, as well as one attempt to enliven, introduce, and maintain the existence of a cultural heritage, batik of Indonesia.

\section{BASIC THEORY}

\section{A. Mobile Application}

According to Irawan (2008:2), mobile application is an application which means access using mobile devices such as mobile phones, smartphones and PDA phone [3]. Nowadays, applications using mobile devices are increasing and diverse. Applications can be made using a proprietary (closed source) development tools. Development tools used is Java 2 Micro Edition (J2ME). The end result of it was placed (embedded) on mobile devices. According Halim Yosiphine (2012), mobile technology or so-called cellular communication technology (Mobile Communication) is currently one of the fastest growing technologies and much in demand by the world community [4].

\section{B. J2ME Programming Language}

Halim Yosiphine said J2ME components consist of a Java 
Virtual Machine (JVM) that is used to run Java applications on emulator or handheld device, Java API (Application Programming Interface) and other tools for developing Java applications for Java Phone sort of emulator, emulator Motorolla of J2ME wireless toolkit [4].

$\mathrm{J} 2 \mathrm{ME}$ is a set of specifications and technologies that focus on consumer devices. This device has a limited amount of memory, spend a little power from the battery, the screen is small and low network bandwidth. J2ME program, like other Java programs are translated by the JAVA VM.

According Irawan (2008:5), J2ME (Java Micro Edition) is a technology backbone for the development of m-commerce today. Some advantages of the use of J2ME are:

1) Create portable applications

2) Good security system

3) Applications can be used in online or offline mode

4) Adopted the main characteristics of the Java applications, "Write once, run anywhere, anytime, and over any device".

\section{Netbeans}

NetBeans is an Integrated Development Environment (IDE) based on Java from Sun Microsystems that runs on top of Swing. Swing is a Java technology for the development of desktop applications that can walks in a variety of platforms such as Windows, Linux, Mac OS X and Solaris.

The NetBeans Platform provides a reliable and flexible modular architecture to application developers [5]. Netbeans is an Open Source software development, in other words, this software is under development together, free of charge. We will get the tools needed to create professional desktop, enterprise, web, and mobile applications using the Java language, $\mathrm{C} / \mathrm{C}++$, and even dynamic languages such as PHP, JavaScript, Groovy, and Ruby. Some advantages netbeans are:

1) Supports a variety of programming languages such as Java, C / C ++ , php

2) Runs on multiplatform operating systems including Windows, Linux, Mac OS, Solaris

3) In function for the development of mobile applications using the Java language

4) Support for the development of web applications using PHP

5) Support software modeling with UML (Unified Modeling Language)

6) There are many modules to further develop

7) Is a free product (read: free) without any usage restrictions

8) Is an open source product (read: open source code).

\section{Global Positioning System (GPS)}

GPS (Global Positioning System) is a satellite navigation system and positioning are owned and managed by the United States. This system is designed to provide threedimensional position and velocity as well as information about the time all over the world continuously without the time and weather dependent, for many people simultaneously. Nowadays, GPS is widely used by people all over the worlds in various applications that require information about the position, velocity, acceleration, or time more thoroughly. GPS becaoming popular, there is growing demand for location-based applications. It is easier, thwew days to utilize map information by connecting GPS receiver to PC and PDA. GPS receivers are now embedded into mobile phones and applications using the location of user in real-time are widely available. [6].

\section{RESEARCH METHODS}

\section{A. Time and Place of Execution}

Implementation of the design and manufacture of this software for about 2 months i.e. August to September 2012. Implementation of the program is housed in the Faculty Research Student Activity Unit (UKMF Penelitian) MATRIKS (Mahasiswa Teknik Riset dan Eksperimen) UNY. Retrieval research data housed in the Department of Electronics Engineering Education for 3 days for the implementation of Alpha Testing. Further data collection was done in UNY for 2 days.

\section{B. Steps of Development}

The approach used in this study using the design approach or Research and Development. Procedures used in the development of this application as it has been developed by experts and include 10 step model of the development of Borg and Gall, which we simplify to 4 steps. In line with it, the steps to be taken in developing the Batik Guide Map application are the steps: (1) needs analysis, (2) design of the model, (3) Implementation (trials), (4) and Validation [7].

\section{Needs Analysis}

Analysis phase proposed to identify and obtain required necessity for the design and implementation of systems and design thinking to the next step. In this phase, the identification data is required for software development. Steps taken in the analysis phase include: a) analysis of motives in Yogyakarta batik b) Places for distributors and Yogyakarta batik courses and c) consumer attitudes towards batik.

\section{Model Design}

Model design is an illustration for explaining overview software concerned on models, contents, size, and color. The design appearance was made that is easy to understand, and use.

\section{E. Implementation (Coding)}

Implementation is the phase of translate design result modules into the application form by using a specific programming language and incorporate them into a more complete unified system. The steps that must be done in the implementation are: (a) collect and choose the modules that will be translated into a programming language, (b) determine the required programs to support programs that have been designed, (c) translating procedures, subroutines and functions of the modules into the programming language, (d) unify procedures, subroutines and functions of modules that have been made into a unified program.

\section{F. Product Validation}

Software testing is the process of knowing shortcomings and errors to determine the feasibility of using Batik Guide 
as a medium to facilitate the Batik consumers in Yogyakarta. This stage includes testing process by experts then revised, and tested on batik consumers as media usage target objects.

\section{G. Object Research}

Object of this research is making Batik Guide softwarebased mobile application. Results of this study will be used to determine the effectiveness of software Batik Guide.

\section{H. Research Instruments}

Instruments that used in this study are proposed to assess the feasibility of software as a Guide to facilitate introduction of Batik. In this research, using tests used, it means implementation of test is did at the same time with actual research implementation and the results of research directly used for further analysis. The assessment material in this research include; the display materials in each page and material capacity.

\section{Techniques of Collection and Analysis Data}

The collection techniques in this research use two steps. First, use the measurement of program functions in accordance with a specific plan. Second, use questionnaire to assess the feasibility of software Batik Guide as supporting media in introducing Batik and the distribution.

Data analysis techniques for the first step are to expose the modified information system product after implemented in software, validation and test the reliability of the program. The second step, by using descriptive qualitative, that step is about the feasibility of the product to be implemented in the process of learning English in elementary school students. Later, data was processed with the specific number and percentage results.

Techniques for data analysis using qualitative is describe the modified media product after implemented in software, and the level of validation and reliability testing program.

$$
\text { Percentage of eligibility }(\%)=\frac{X t}{X y} \times 100 \%
$$

where $X t$ is the score worthiness; $X y=$ maximum score; $\%=$ percentage of eligibility. Furthermore, data were analyzed with in frequency distribution and percentage of the category rating scale that has been determined as a percentage score, shown descriptively and take the conclusions in each indicator can be seen in the Table I.

TABLE I: TABLE OF CONFORMITY ASSESSMENT SCALE MEDIA PRODUCT
\begin{tabular}{|c|c|c|}
\hline $\begin{array}{c}\text { Percentage of } \\
\text { attainment }\end{array}$ & Scale & Interpretation \\
\hline $80-100 \%$ & 4 & Very high \\
\hline $60-79 \%$ & 3 & high \\
\hline $40-59 \%$ & 2 & Adequate \\
\hline $0-39 \%$ & 1 & Low \\
\hline
\end{tabular}

\section{RESULT}

\section{A. Batik Guide Mobile Application}

\section{1) Architectural design}

Architectural design is the images of the elements/ software functional components are arranged, organized, and structured so that relationships between elements/ components can be explained and defined. For the architectural design of Batik Guide Application can be seen in Fig. 1. Fig. 1 is architectural design of Batik Guide Application. From Fig. 1 can be seen components of Batik Guide Application.

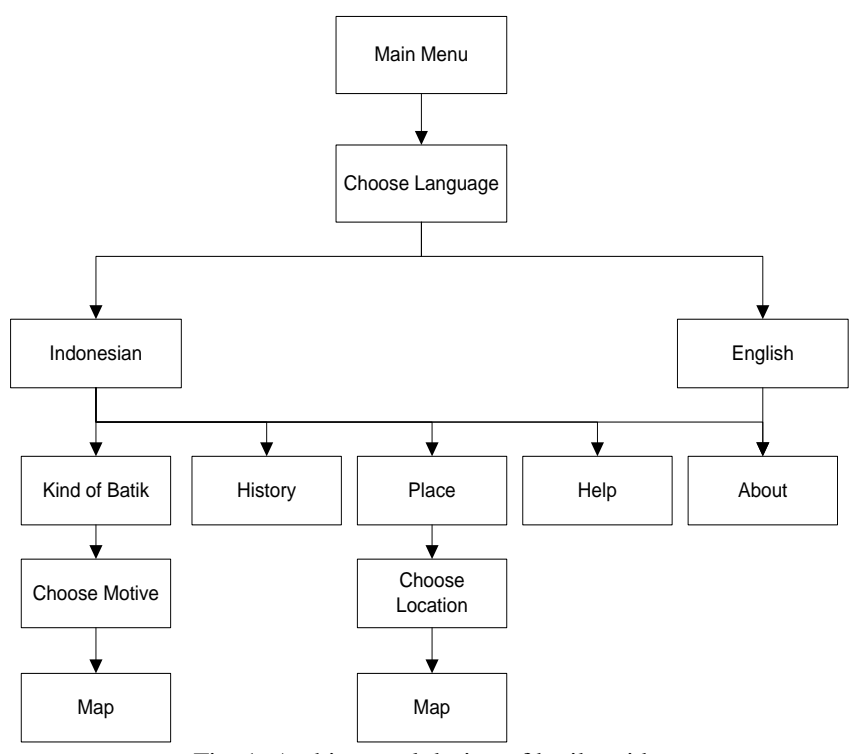

Fig. 1. Architectural design of batik guide.

\section{2) Screenshot programme}

After implementation of the program, then we will got screenshot of the program. For the screenshot of Batik Guide Application can be seen in Fig. 2.

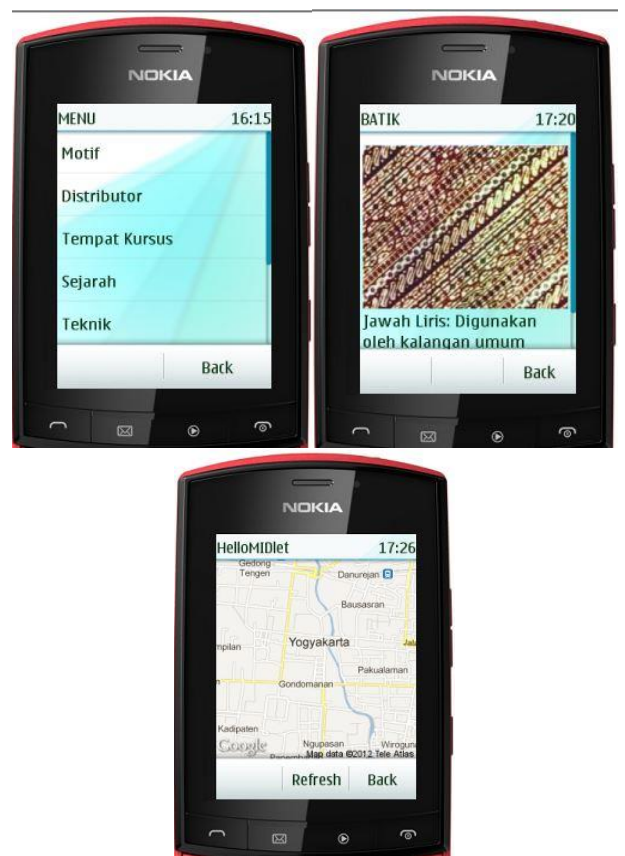

Fig. 2. Screenshot of batik guide application.

From Fig. 2, can be seen function description of the menus in the software Batik Guide are:

1) Logo, first displayed view is displayed of the software Batik Guide then after that will go on the page menus of software.

2) Language choices, selects one of the familiar languages for user. 
3) Motif, menu to see the kind of motif. The menu will lead user to know all kinds of menu Yogyakarta batik.

4) Distributor, menu to see the distributor address of Batik in Yogyakarta.

5) The course, menu to see the address of the Batik course place in Yogyakarta

6) History, menu to see the history of batik in Yogayakarta.

7) Techniques, menu to see the technique of batik in Yogyakarta.

8) Help, to see usage instructions Batik Guide.

9) About, contains descriptions and information about the software.

10) Exit, to exit the software.

\section{3) Examination}

Results of the research instrument data processing to media expert and expert programming. In Batik Guide, kinds of data Batik motif is specifically original batik in Yogyakarta because there are many modified motif in modern Batik. This batik data were get from survey in the center of batik Tjokrosoeharto. From the results of testing and sampling data then can be analyzed the performanceand software quality.

TABLE II: TEST RESULTS BY EXPERT MEDIA

\begin{tabular}{|l|l|l|l|}
\hline No. & Aspek Score & $\%$ \\
\hline 1. & Design Aspects Information & 32 & 75 \\
\hline 2. & $\begin{array}{l}\text { Clarity } \\
\text { Aspects }\end{array}$ & 87,5 \\
\hline 3. & Benefits Aspects & 24 & 91,6667 \\
\hline & Total & 92 & $\mathbf{8 4 , 7 2}$ \\
\hline
\end{tabular}

According to the Table II is known that software Batik Guide gets a very appropriate category with $84.72 \%$.

Media Expert Conclusion:

1) Display interfaces in software applications better made more colorful.

2) Systematics of writing is regular.

3) Placement of tools and navigation buttons is appropriate with multimedia literature.

4) Media using is efficient, can help user in identifying Batik.

5) Software suitable for field tested with the revision suggestions.

Besides, Beta Testing is use for testing process of fix software to the sample (UNY students and the community around the UNY campus), the value of the test results instrument obtained from the study of 30 people to determine the feasibility of software.

According to the table is known that the effectiveness of Batik Software Guide is $92 \%$. It can be concluded that the software is proper to use as a media introduction of Batik in Yogyakarta.

\section{CONCLUSION}

Based on the results of software making is concluded:

1) Batik Guide Map application design is done through several steps of need assesment, design, implementation (coding) and testing.

2) To determine software feasibility was done with testing the software on two expert lecturers and got a rate of $84.72 \%$. Aspects of the testing are design, clarity of information and benefits.

3) To determine the feasibility of software on the user then tested on 30 respondents and get a feasibility level of $92 \%$. Application also tested on three tourists from the Netherlands and France who declared this application is to help them in identifying Batik.

\section{ACKNOWLEDGEMENTS}

With the completion of this study, we would like to thank: Dr. Rahmat Wahab, M. A. as Rector of the State University of Yogyakarta.

Dr. Mochamad Bruri Triyono as Dean of the Faculty of Engineering, Yogyakarta State University.

Mr. Drs. Muhammad Munir, MPd as Chairman of the Department of Electronics Engineering Education.

Dr. Ratna Wardani as the supervisor who has given directions to the completion of this final report.

Mr. Handaru Teak, Ph.D. who given support and direction.

Parents and family we were always given me endless support and prayers.

MATRIKS UKMF friends who always gave encouragement to remain "Work and contribute".

All concerned that I can not mention one by one that has provided relief material and sprituil. May your kindness be acts of worship.

\section{REFERENCES}

[1] S. B. Yudhoyono (2011). Batik Termasuk Ekonomi Kreatif Yang Terus Berkembang. [Online]. Available: http://www.presidenri.go.id/index.php/fokus/2011/09/28/7252.html.

[2] F. Muhammad (2012). Saat Nomor Seluler Lampaui Jumlah Penduduk. [Online]. Available: http://bola.viva.co.id/print_detail/printing/279887-jumlah-nomor seluler-lewati-jumlah-penduduk.

[3] Irawan, Java Mobile untuk Orang Awam, Palembang: Maxikom. 2008.

[4] H. Yosiphine, "ALgorithma Extended Weighted tree Similiatary untuk Memberikan Solusi Memasak pada J2ME," Thesis, Dept. Informatic.Eng. Sam Ratulangi University, Manado, Indonesia, 2011.

[5] H. Martin, "An Evaluation of the Netbeans Modul System as a Product line Implementation Technology," presented at the ICMCE, Amerika, 2011.

[6] P. Shah. (May 2012). Location Based Reminder Using GPS For Mobile (Android). ARPN. [Online]. 2(4). p. 378. Available: http://www.ejournalofscience.org/archive/vol2no4/vol2no4_14.pdf

[7] D. Gall and L. Borg, Educational Research: An Introduction, New York: Longman, 1983

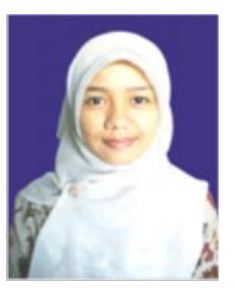

Tika Novita Sari was born on November, $7^{\text {th }} 1992$ in Sleman, Yogyakarta, Indonesia. She started her study when she was seven years old in Sempu Elementary School (SDN Sempu) in her village. She was graduated in 2005 and continued her study in $1^{\text {st }}$ Ngemplak Junior High School (SMPN 1 Ngemplak).

In 2008 she continued her study in $8^{\text {th }}$ Yogyakarta Senior High School (SMAN 8 Yogyakarta) in the city of Yogyakarta. She took acceleration class. At that time, she was always active in a research in her school, called KIR. She finished her study in 2010 and continued again for her first degree (S1) in Yogyakarta State University, in Yogyakarta. She took Informatics Engineering Education Department on Engineering Faculty. Now, she is in seventh semester.

She had joined some organizations since she was in first semester such as research and engineering. She ever got First Winner with her friends on "Lomba Karya Tulis" in 2012. She also got $1^{\text {st }}$ Winner with her friends for "Technologies Competition" in 2012 and many more. She had many achievements. Now, she is doing thesis and also be an entrepreneur. Her papers were published in ILCC 2013 journal. 


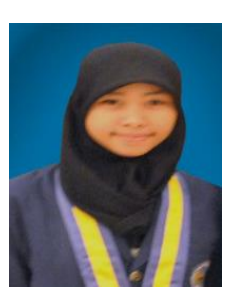

Amalia Ima Nur Jayanti was born on October, $12^{\text {th }}$ 1991 in Sleman, Yogyakarta, Indonesia. She started her study when she was seven years old in Sidorejo Elementary Schook (SDN Sidorejo). She was graduated in 2004 and she continued her study in $1^{\text {st }}$ Kalasan Junior High School (SMP N 1 Kalasan).

In 2008 she continued her study in 1th Depok Senior High School (SMAN 1 Depok) in the city of Yogyakarta. She finished her study in 2010 and she continued again for her degree (S1) in Yogyakarta State University, in Yogyakarta. She took Informatic Engineering Education Department on Engineering Faculty. Now, she is in seventh semester.

She had joined some organizations since she was in first semester such as research and engineering. She ever got winner with her friends on research competitions and many more. She had many achievements. She also joined many organization in her village, such as youth organization and soon. Now she is doing with her thesis.

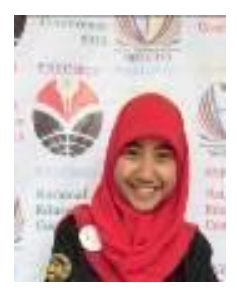

Rohmatus Naini is a student majoring in psychology education and guidance, Faculty of Education Yogyakarta State University, Indonesia. She presented in the $6^{\text {th }}$ ICER 2013 in Khon Khaen University Thailand, and her research interests are in multiple intelligence and presented in National of education conference in UPI-Bandung. But this paper she did research with Tika Novita Sari et al. She had some achievement in paper competition.

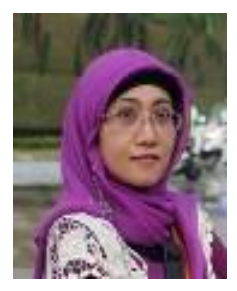

Ratna Wardani is a lecturer at the Department of Electronic Engineering Education, Faculty of Engineering Yogyakarta State University, Indonesia. She holds a PhD degree in quality of service for low quality internet connection from Department of Electrical Engineering and Information Technology at Gadjah Mada University, Indonesia. She received a master degree of engineering in information technology feom Gadjah Mada University and Undergraduate in Computer Science from the same university. Her research interests are in QoS for low quality Internet connection and IT in education. 